\title{
Changes in soil microbial community structure and metabolic activity following conversion from native Pinus massoniana plantations to exotic Eucalyptus plantations
}

\author{
Falin Chen $^{\text {a }}$, Hua Zheng ${ }^{\mathrm{a}, *}$, Kai Zhang ${ }^{\mathrm{a}}$, Zhiyun Ouyang ${ }^{\mathrm{a}}$, Jun Lan ${ }^{\mathrm{b}}$, Huailin Li $^{\mathrm{b}}$, Qian Shi ${ }^{\mathrm{b}}$ \\ a State Key Laboratory of Urban and Regional Ecology, Research Center for Eco-Environmental Sciences, Chinese Academy of Sciences, Beijing 100085, China \\ ${ }^{\mathrm{b}}$ Guangxi State Dongmen Forest Farm, Fusui 532108, China
}

\section{A R T I C L E I N F O}

\section{Article history:}

Received 6 September 2012

Received in revised form 13 November 2012

Accepted 16 November 2012

Available online 7 January 2013

\section{Keywords:}

Forest conversion

Soil microbial structure

Soil microbial community metabolism

Exotic species

Eucalyptus

\begin{abstract}
A B S T R A C T
Afforestation after deforestation using fast growing exotic species is creating major land use changes throughout China and the world. However, few studies have looked at changes in soil microbial communities resulting from the planting of exotic species. With paired comparison design, we studied the effects of replacing a native Pinus massoniana plantation with an exotic Eucalyptus (Eucalyptus urophylla $\times$ grandis) plantation on the composition and carbon metabolic function of soil microbial communities in Guangxi Province, southern China. We compared the microbial biomass, phospholipid fatty acid (PLFA) composition and carbon metabolic function (BIOLOG profiles) between both plantation types. Results showed the abundance of bacterial, fungal, actinomycetal, and total phospholipid fatty acids, and the proportion of $16: 1 \omega 5 \mathrm{c}$ and five gram-negative characteristic bacterial PLFAs (of the six detected) in the Eucalyptus plantation soils were significantly lower than those of the P. massoniana plantations, as were biomass, carbon metabolic activity, and richness and diversity of the soil microbial community. The indicators denoting stress related to soil nutrient levels were significantly higher in the Eucalyptus plantation soils, such as the ratios of monounsaturated to saturated fatty acid, gram ${ }^{+}$to gram ${ }^{-}$bacteria, iso- to anteiso-branched PLFA, and cy19:0 to 18:1 $\omega 7 \mathrm{c}$. Canonical correspondence analysis (CCA) indicated the significant changes in the soil microbial community were mainly due to shrub and herb coverage, soil water content, soil organic carbon, soil N:P, and available N. Our research suggests forest conversion from native P. massoniana plantations to exotic Eucalyptus plantations alters the structure and function of the soil microbial community driven mainly by shifts in understory coverage and soil resource availability. Improved management practices, such as litter retention, reducing soil or understory disturbance during logging and subsequent establishment of the next rotation plantation, should be considered to help improve the metabolic function of soil microbial communities and increase soil resource availability during plantation management.
\end{abstract}

(c) 2012 Elsevier B.V. All rights reserved.

\section{Introduction}

Over the past century, humans have dramatically changed the structure and function of ecosystems across the globe. Deforestation followed by afforestation with fast growing exotic species, such as Eucalyptus, is one of the most significant ecological changes facing China and the world (Sicardi et al., 2004; Berthrong et al., 2009; Burton et al., 2010; Iovieno et al., 2010). The widespread anthropogenic dispersal of exotic species is raising concern over their potentially devastating ecological impacts on native ecosys-

* Corresponding author. Address: State Key Laboratory of Urban and Regional Ecology, Research Center for Eco-Environmental Sciences, Chinese Academy of Sciences, Shuangqing Road 18, Haidian District, P.O. BOX 2871, Beijing 100085, China. Tel.: +86 10 62849815; fax: +86 1062943822 .

E-mail address: Zhenghua@rcees.ac.cn (H. Zheng). tems (Ehrenfeld, 2003, 2010; Wardle et al., 2012). The rapid growth rates of exotic species plantations, when compared to native forest, have shown to exhaust soil water and nutrient resources (Turnbull, 1999), alter the quantity or quality of carbon input (Rothstein et al., 2004), and prevent understory vegetative growth by direct physical disturbance (weed control or other forestry-related activities) (Zhu et al., 2009) or direct chemical interference (Zhang and Fu, 2009). Exotic plants can also disrupt ecological associations between soil microbial communities and previous native communities (Kasel et al., 2008), thus resulting in decreased biodiversity, soil erosion, and losses in fertility (Wei et al., 2009).

Globally, Eucalyptus is the second most common genus used for afforestation and is a common choice for reforestation in southern China because of it is fast growing and highly adaptable to various environments. From the early 1950s, planting of Eucalyptus in- 
creased substantially because of its attractive shape and economic value, which resulted in the planting of 3,680,000 ha by the end of 2010 (China Eucalypt Research Centre www.chinaeuc.com/show.asp?id=544). However, the introduction of Eucalyptus can have deleterious effects on the local environment (e.g. biodiversity losses, soil erosion, and soil fertility decline) that undermine its benefits (Berthrong et al., 2009; Lynch et al., 2012). Afforestation of exotic Eucalyptus plantations is known to affect the physical and chemical properties of the soil, and plant community biodiversity (Wen et al., 2009; Zhu et al., 2009), but little attention has been given to the effects of Eucalyptus plantations on soil microbial communities in southern China.

Soil microorganisms play a central role in decomposition, nutrient mineralization, and nearly all soil ecological processes in forest ecosystems. Soil microorganisms play a key role in forest ecosystem function and the sustainability of soil nutrients (Xu et al., 2008; Burton et al., 2010). Large-scale environmental perturbations, such as plantation conversion, can cause large shifts in the soil microbial community. In addition, soil microbial properties are more sensitive to land use changes than soil chemical and physical properties (Romaniuk et al., 2011). Soil microbial biomass and carbon metabolic activity have traditionally been used as indicators of soil fertility, with decreases of the above indicators indicating a decline in soil quality (Wardle, 1992; Zheng et al., 2005). Furthermore, changes in soil microbial community composition (e.g., the ratios of saturated to monounsaturated fatty acid, fungi to bacteria, gram ${ }^{+}$to gram $^{-}$bacteria, iso- to anteiso-branched phospholipid fatty acid (PLFA), and cyclopropyl fatty acid to precursors) also positively correlate with soil nutritional stress or negatively with resource availability (Bossio and Scow, 1998; Fierer et al., 2003; McKinley et al., 2005; Moore-Kucera and Dick, 2008). Understanding how environmental changes affect soil microbial communities will help predict how biogeochemical cycles respond to plantation conversion more broadly and enhance the sustainable management of plantations.

The goal of this study was to examine: (1) how soil microbial biomass, compositional structure and carbon metabolic functions responded to plantation conversion and (2) the main environmental factors causing changes in soil microbial communities after plantation conversion. For these objectives, we studied the effects of replacing a native Pinus massoniana plantation with an exotic Eucalyptus spp. plantation on the composition and carbon metabolic function of soil microbial communities by quantifying and comparing microbial biomass, PLFA composition, and carbon metabolic profiles. Lastly, this study provided a management baseline for improving the function of soil microbial communities.

\section{Materials and methods}

\subsection{Study area}

The study was conducted at Fusui County, Guangxi Province $\left(107^{\circ} 47^{\prime}-107^{\circ} 56^{\prime} \mathrm{E}, 22^{\circ} 14^{\prime}-22^{\circ} 21^{\prime} \mathrm{N}\right)$, China. Guangxi Province has the largest combined area of Eucalyptus plantations in Asia. By 2010, the area of Eucalyptus plantations totaled more than 1.6 million ha (Guangxi Zhuang Autonomous Regional Forestry Department, www.gxly.cn:8888/pub/cms/1/3545/3559/3566/ 88982.html), approximately $40-50 \%$ from the conversion of P. massoniana plantations to Eucalyptus plantations (Zhu et al., 2009).

The area ranges from 160 to $410 \mathrm{~m}$ in elevation. The mean annual temperature is $21.2-22.3^{\circ} \mathrm{C}$ and mean annual precipitation is $1100-1300 \mathrm{~mm}$ (Ye et al., 2010). Soils in the region are mainly lateritic red earth with a typical soil depth of $80 \mathrm{~cm}$ or more and are derived from arenaceous shale with a $\mathrm{pH}$ ranging from 4 to 5 .
The flora of $P$. massoniana plantations and Eucalyptus plantations host different dominant plant species. P. massoniana plantations are dominated by $P$. massoniana, Euodia lepta, Mallotus barbatus, Toxicodendron succedaneum, Geum aleppicum, Eurya groffii, Ficus hirta, Phyllanthus emblica, Rubus cochinchinensis, Dicranopteris dichotoma, and Miscanthus floridulu. However, Eucalyptus plantations are dominated by Eucalyptus spp., M. barbatus, Geum aleppicum, Trema cannabina, Rhus chinensis, Miscanthus floridulus, and Cyrtococcum paten. Herbs are the more dominant in the understory of Eucalyptus plantations than P. massoniana.

In this region Eucalyptus plantations have typically undergone considerable site preparation including the removal of shrubs and weeds prior to reforestation often with prescribed fire. Eucalypt special fertilizer is typically applied to promote growth, with $500 \mathrm{~g} /$ plant as a base fertilizer during plantation establishment and $250 \mathrm{~g} /$ plant as supplemental fertilizer at 6,12, and 24 months after planting. In each Eucalyptus plantation prescribed weed control was performed annually.

\subsection{Experimental design and sampling}

We used a paired comparison design to evaluate the influence of Eucalyptus afforestation on the soil microbial community. Eight pairs of sites were selected in which each pair included adjacent sites with a native P. massoniana plantation and an exotic Eucalyptus urophylla $\times$ grandis plantation. Each site was greater than 1 ha, and the Eucalyptus plantation sites were established between 2000 and 2005. Prior to reforestation, the Eucalyptus plantation sites were native $P$. massoniana plantations like their adjacent controls.

Three composite soil samples were collected from each Eucalyptus and P. massoniana plantation site (six composite samples for one paired site) in October 2010. A composite sample was a mix of ten cores $(0-10 \mathrm{~cm}$ depth), which were taken using a $3.6 \mathrm{~cm}$ diameter soil core after removal of vegetation and litter. All the soil samples were stored on ice for transport to the laboratory.

Soil samples were homogenized and sieved $(2 \mathrm{~mm})$ to remove plant debris, soil fauna, and rocks. Microbial biomass $\mathrm{C}$ and BIOLOG assays were performed immediately on fresh soil and a portion of soil was immediately frozen at $-20^{\circ} \mathrm{C}$ for subsequent PLFA analysis. Subsamples were air-dried for analysis of the basic physical and chemical characteristics of the soil.

Also during the soil sampling we surveyed the plant communities. At each site, we identified all species within three $20 \times 20 \mathrm{~m}^{2}$ plots for trees, five $5 \times 5 \mathrm{~m}^{2}$ plots for shrubs and nine $1 \times 1 \mathrm{~m}^{2}$ plots for herbs. The coverage of tree, shrub, and herb layers were also determined by visual estimation.

\subsection{Soil physicochemical analysis}

Soil moisture content was determined gravimetrically by weighing the soil sample, drying it in an oven at $105^{\circ} \mathrm{C}$ for $24 \mathrm{~h}$ and then re-weighing the sample. Soil $\mathrm{pH}$ was determined in a 1:2.5 soil-water slurry using Delta $320 \mathrm{pH}$ meter (Meltler-Toledo Instruments (Shanghai) Co., Ltd.). The sizes of soil particles were measured using a Mastersizer 2000 (Malvern Instruments, Malvern, England) according to Wang et al. (2008), and the particle size distribution were categorized according to the US soil classification system (Huang, 1999). Soil total C and N were determined by combustion in a Vario EL III Elemental Analyzer (Elementar Analysen Syetem GmbH, Germany). Soil organic carbon was measured by wet oxidation using dichromate in acid medium followed by the $\mathrm{FeSO}_{4}$ titration method (Bao, 2000). Alkaline hydrolytic nitrogen was measured using the boric acid absorption - hydrochloric acid titration method (Bao, 2000). Soil was digested using sulfuric acid and perchloric acid, and total phosphorus and potassium were measured using a Prodigy High Dispersion ICP-OES 
(Teledyne Technologies Incorporated, USA). Sulfuric acid and hydrochloric acid were used to extract and measure available phosphorus in the soil, and an ammonium acetate solution was used to extract and measure available potassium (Bao, 2000). Available phosphorus and available potassium were measured using a Prodigy High Dispersion ICP-OES.

\subsection{Microbial biomass $C$}

To measure microbial biomass C, soil samples ( $20 \mathrm{~g}$ ) were fumigated for $24 \mathrm{~h}$ under ethanol-free chloroform, then extracted in $80 \mathrm{ml} 0.5 \mathrm{M} \cdot \mathrm{K}_{2} \mathrm{SO}_{4}$ (soil/extractant ratio 1:4). Samples were shaken at $200 \mathrm{r} \mathrm{min}^{-1}$ for $30 \mathrm{~min}$, and filtered through double quantitative filter paper. A corresponding set of unfumigated samples were similarly extracted (Vance et al., 1987). The content of $\mathrm{K}_{2} \mathrm{SO}_{4}$-extracted $\mathrm{C}$ from the $\mathrm{CHCl}_{3}$-fumigated and unfumigated soils was determined by an automated TOC analyzer (Liqui TOC, Elementa, Germany). The conversion factor for calculation of microbial biomass $C$ was 0.45 .

\subsection{PLFA analysis}

Soil microbial community structure was characterized using PLFA analysis as described by the modified Buyer method (Buyer et al., 2010). Four grams of lyophilized soil were placed in a $30 \mathrm{ml}$ glass centrifuge tube with a Teflon-lined screw cap, and $3.2 \mathrm{ml}$ of $100 \mathrm{mM}$ phosphate buffer (pH 7.4), $8 \mathrm{ml}$ of methanol, and $4 \mathrm{ml}$ of chloroform were added. Tubes were sonicated for $10 \mathrm{~min}$ in a sonicating water bath and then rotated end over end for $1 \mathrm{~h}$ at room temperature. After centrifugation for $10 \mathrm{~min}$ at $2500 \mathrm{rpm}$, the liquid phase was transferred to a $30 \mathrm{ml}$ separatory funnel. Another $3.2 \mathrm{ml}$ of $100 \mathrm{mM}$ phosphate buffer and $4 \mathrm{ml}$ of chloroform were added then the mixture was shaken vigorously, and allowed to separate overnight. The bottom (organic phase) was evaporated under $\mathrm{N}_{2}$.

Lipid classes were separated by solid phase extraction (SPE) chromatography using a $500 \mathrm{mg}$ silica gel column (Part No. 5982-2265, Agilent Technologies, Wilmington, DE, USA) which had been pre-washed with $5 \mathrm{ml}$ of chloroform. After loading the extract in chloroform, neutral lipids were eluted with $10 \mathrm{ml}$ of chloroform, polar lipids were eluted with $10 \mathrm{ml}$ of acetone, and phospholipids were eluted with $5 \mathrm{ml}$ of methanol. The phospholipid fraction was evaporated under $\mathrm{N}_{2}$.

Fatty acids were transesterified with $1 \mathrm{ml}$ of $1: 1$ methanol:toluene and $1 \mathrm{ml}$ of $0.2 \mathrm{M}$ methanolic $\mathrm{KOH}$ at $35^{\circ} \mathrm{C}$ for $15 \mathrm{~min}$. After adding $2 \mathrm{ml}$ of 1:4 chloroform:hexane, $1 \mathrm{ml}$ of $1 \mathrm{M}$ acetic acid, and $2 \mathrm{ml}$ of $\mathrm{ddH}_{2} \mathrm{O}$, the mixture was vortexed and the phases allowed to separate for $5 \mathrm{~min}$ at $2000 \mathrm{rpm}$. The top phase was removed and the bottom phase repeated with an additional $2 \mathrm{ml}$ of 1:4 chloroform:hexane. The combined organic phase was evaporated under $\mathrm{N}_{2}$ and stored at $-20^{\circ} \mathrm{C}$.

The extracts were cleaned by SPE using an $\mathrm{NH}_{2}$ SPE column (Part No. 8B-S009-EAK, Phenomenex, Torrance, CA) pre-washed with $1 \mathrm{ml}$ of chloroform. Samples were eluted with $1 \mathrm{ml}$ of chloroform and loaded onto the column. After evaporation under $\mathrm{N}_{2}$, samples were dissolved in $1 \mathrm{ml}$ of hexane including $10 \mu \mathrm{g} / \mathrm{ml}$ methyl nonadecanoate (19:0) before analysis.

The fatty acid methyl esters were separated on a gas chromatograph with a flame ionization detector (GC-FID) (HP 6890, Agilent Technologies, Santa Clara, CA) using an HP-5 fused silica capillary column $(30 \mathrm{~m} \times 0.25 \mathrm{~mm} \times 0.25 \mu \mathrm{m})$. Helium was used as the carrier gas at $1.0 \mathrm{ml} / \mathrm{min}$. Splitless injection was employed. Temperature specifications were set to: injector temperature $230{ }^{\circ} \mathrm{C}$, detector $270{ }^{\circ} \mathrm{C}$; temperature program: $50^{\circ} \mathrm{C}$ for $1 \mathrm{~min}$, then $15^{\circ} \mathrm{C} / \mathrm{min}$ to $150{ }^{\circ} \mathrm{C}$, maintained for $2 \mathrm{~min}$, and then $3{ }^{\circ} \mathrm{C} / \mathrm{min}$ to $250^{\circ} \mathrm{C}$ with a final hold of $15 \mathrm{~min}$. The individual PLFA peaks were identified by GC-MS (gas chromatograph combined with mass selective detector HP 5973, Agilent Technologies, Santa Clara, CA).

Mass spectrometer peak identification was based on comparison with the spectra of commercially available bacterial methyl ester (BAME) mix standards (Sigma, St. Louis, MO) and the software library NIST05.L. For each sample, different PLFAs were considered to be the representative of different groups of soil micro-organisms. All of the identified PLFAs were considered representative of the total PLFAs of the soil microbial community (Tunlid et al., 1989; Wu et al., 2011). Twenty-five PLFAs were included in the analysis of total PLFA abundance. The following PLFAs identified bacterial groups: i15:0, a15:0, 15:0, i16:0, 16:1 $\omega 9 \mathrm{t}, 16: 1 \omega 7 \mathrm{c}$,

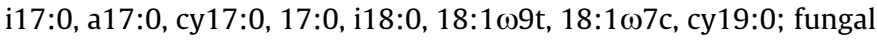
groups: $16: 1 \omega 5 c, 18: 2 \omega 6,9 c, 18: 1 \omega 9 c$; actinomycetic groups: 10Me17:0 and 10Me19:0; and 14:0, 16:0, 18:0 were normal PLFAs (Frostegård and Bååth, 1996; Zelles, 1997, 1999; Zelles et al., 1997; Olsson, 1999).

\subsection{BIOLOG analysis}

A BIOLOG Microstation System (BIOLOG Inc., Hayward, CA, USA) was used to study the metabolic function of the soil microbial community (Winding, 1994). The BIOLOG technique proposes a simple and sensitive way to compare potential metabolic diversity of soil microbial communities (predominantly bacterial) (Campbell et al., 1997). Despite the BIOLOG MicroPlates not necessarily giving a complete metabolic fingerprint of the soil microbial communities, only representing certain metabolic functions in the MicroPlates, the outcomes reflected the patterns of carbon source utilization (Preston-Mafham et al., 2002; Zheng et al., 2005). BIOLOG MicroPlate breathprint reflects diversity of carbon-oxidation pathways, and therefore functional diversity of soil microbial communities (Wu et al., 2011). This kind of functional diversity could provide a minimum estimate of taxonomic diversity on an equal basis (Stephan et al., 2000). BIOLOG has been widely used in assessing microbial metabolic diversity in agricultural soils, forest soils, and under various vegetations (Zak et al., 1994; Grayston et al., 1998; Zheng et al., 2005). Increased understanding of the BIOLOG assay has revealed the reproducibility of BIOLOG profiles, and supports the theory that shifts in BIOLOG metabolic diversity patterns relate to shifts in community composition (Haack et al., 1995).

The commercially available BIOLOG Ecoplate (BIOLOG Inc., Hayward, CA, USA) comprise three replicate sets of 31 substrates, which are ecologically relevant, structurally diverse compounds (e.g. plant root exudates). These substrates are widely used to assess functional diversity of soil microbial communities, and are based on community-level carbon sources utilization patterns (Preston-Mafham et al., 2002). We used EcoPlate to compare potential metabolic diversity of soil microbial communities between the two plantations. Briefly, $10 \mathrm{~g}$ of fresh soil was added to $90 \mathrm{ml}$ of sterilized $0.145 \mathrm{~mol} \mathrm{l}^{-1} \mathrm{NaCl}$ in a $200 \mathrm{ml}$ flask and shaken at $200 \mathrm{r} \mathrm{min}^{-1}$ for $30 \mathrm{~min}$ to achieve a $10^{-1}$ soil slurry. Ten-fold serial dilutions were prepared and $150 \mu \mathrm{l}$ of the $10^{-3}$ suspension was inoculated into each well of the BIOLOG EcoPlates. The plates were incubated at $25^{\circ} \mathrm{C}$ for 10 days and color development was read as absorbance every $12 \mathrm{~h}$ with an automated plate reader (VMAX, Molecular Devices, Crawley, UK) at a wavelength of $590 \mathrm{~nm}$. The data were collected using Microlog 4.01 software (BIOLOG Inc.) (Winding, 1994).

\subsection{Data processing and analysis}

The color development in BIOLOG plates was expressed as average well color development $(A W C D)$ following Garland and Mills (1991): 
$A W C D=\sum_{i=1}^{31}\left(C_{i}-r\right) / n$

where $C_{i}$ was the absorbance of the $i$ th substrate following incubation measured in terms of optical density at a wavelength of $590 \mathrm{~nm}$ $\left(\mathrm{OD}_{590}\right), r$ was the comparable absorbance of contrast well. $n$ was the number of substrates involved (i.e. 31 in our study). Negative $\left(C_{i}-r\right)$ values were set to zero (Kohler et al., 2005). Statistically, the area under the $A W C D$ curve is a particularly useful summary, as differences between treatments in the maximum color development, or in the rates of color development, resulting in different areas under the time-course profile. The soil microbial activity of carbon source utilization $(S)$ may be estimated by the area underneath $A W C D$ vs. $t$, and was obtained by integrating the equation against time $t$ (Hackett and Griffiths, 1997):

$S=\sum\left[\left(v_{i}+v_{i-1}\right) / 2 \times\left(t_{i}+t_{i-1}\right)\right]$

where $v_{i}$ was average optical density of the ith incubation time.

BIOLOG data incubated for $72 \mathrm{~h}$ were analyzed according to Zak et al. (1994) to give catabolic richness (total number of wells with absorbance over $0.25, S_{1}$ ) and catabolic diversity (Shannon-Weiner diversity index, $H^{\prime}$ ). The microbial community functional diversity indicated by the Shannon-Weiner diversity index was calculated as:

$H^{\prime}=-\sum P_{i} \ln P_{i}$

and $P_{i}=n_{i} / N$, where $n_{i}$ was the absorbance of the $i$ th carbon source and $N$ was the total absorbance of all carbon sources.

We assessed the significant differences in plant and soil properties, microbial biomass, structure, and function variables between the P. massoniana plantation and the Eucalyptus plantation using paired-samples $t$ tests in the SPSS 16.0 software package (SPSS INC., Chicago, IL). The level of replication was one pair of plantation sites.

Multi-response permutation procedure (MRPP) was used to examine differences in the PLFA composition and carbon utilization profiles of the soil microbial communities between the two plantation types. The Bray-Curtis dissimilarity index was used to calculate the distance matrix from the PLFA/BIOLOG data. The Monte Carlo permutation test (999 times) was used to test the significance of the statistical results (Mielke and Berry, 2001; Weand et al., 2010).

The relationships between the environmental variables and the soil microbial community were analyzed via the partial canonical correspondence analysis (partial CCA). Partial CCA were performed with CANOCO 4.5. "Species" data were centered and "environment" data were standardized (Kaufmann et al., 2004). BIOLOG "Species" data was represented by utilized carbon source (i.e., the optical intensity of carbon source calculated by $\left(C_{i}-r\right)$ at $72 \mathrm{~h}$ after the incubation). PLFA "Species" data was represented by the PLFAs relative abundance, and only those PLFAs with mean \%mole abundance $>1 \%$ were used in the ordination analyses (16 PLFAs) to avoid bias from rare but low abundance PLFAs (Weand et al., 2010). Fifteen soil factors and six plant factors were used as causative factors. The soil factors included $\mathrm{pH}$, contents of moisture, clay, silt, total $\mathrm{C}$, total $\mathrm{N}$, total $\mathrm{P}$, total $\mathrm{K}$, organic $\mathrm{C}$, alkalihydrolysable $\mathrm{N}$, available $\mathrm{P}$, and available $\mathrm{K}, \mathrm{C}: \mathrm{N}, \mathrm{C}: \mathrm{P}$ and $\mathrm{N}: \mathrm{P}$. The plant factors included species richness in shrub layer and herb layer, coverage of tree layer, shrub layer, and herb layer. BIO-ENV procedures were used to preselect factors with the best correlation between the measured plant and soil variables and the PLFA composition or the carbon metabolic patterns of soil microbial community (Clarke and Ainsworth, 1993) for partial CCA. MRPP and BIO-ENV procedures were performed with the Vegan package (v.1.17-5) in $\mathrm{R}$ version 2.11.1.

\section{Results}

\subsection{Microbial biomass carbon}

Significant differences were found in the biomass of the soil microbial communities in Eucalyptus and P. massoniana plantations. Soil microbial biomass $C$ ranged from $262-752 \mu \mathrm{g} \mathrm{g}^{-1}$ soil in Eucalyptus plantations and from $446-1109 \mu \mathrm{g} \mathrm{g}^{-1}$ soil in P. massoniana plantations. The soil microbial biomass $\mathrm{C}$ of Eucalyptus plantations were significantly lower than those of $P$. massoniana plantations $(P<0.05)$.

\subsection{Microbial community composition}

Total PLFAs ranged from $32.67-77.22 \mathrm{nmol} \mathrm{g}^{-1}$ soil in Eucalyptus plantations and from $58.38-121.15 \mathrm{nmol} \mathrm{g}^{-1}$ soil in P. massoniana plantations. The abundance of bacterial, fungal, actinomycetic PLFAs, and total PLFAs in Eucalyptus plantations were significantly lower than those of the adjacent $P$. massoniana plantations (Fig. 1).

Eucalyptus planting had significant effects on the PLFA composition of soil microbial communities (MRPP, observed $\delta=0.067$, expected $\delta=0.081, P=0.001$ ). The proportion (expressed in moles percent) of $16: 1 \omega 5 c$, which indicates arbuscular mycorrhizal fungi, and five gram-negative bacterial characteristic PLFAs (of the six detected) in the Eucalyptus plantation soils were significant lower than those of adjacent P. massoniana plantations (Fig. 2).

In addition, the ratios of normal saturated to monounsaturated fatty acids, gram-positive to gram-negative bacteria, iso- to ante-

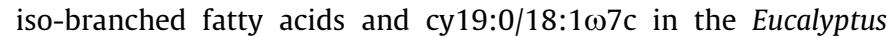
plantation soils were significantly higher than those of $P$. massoniana plantation soils (Table 1 ), which usually indicate nutrient deficiencies in soils (Bossio and Scow, 1998; Fierer et al., 2003; McKinley et al., 2005; Moore-Kucera and Dick, 2008).

\subsection{Carbon source metabolism function}

Carbon source metabolism function differed significantly between the two plantation types. Conversion of native $P$. massoniana plantations to exotic Eucalyptus plantations changed the carbon utilization profiles of the soil microbial community (MRPP, observed $\delta=0.178$, expected $\delta=0.234, P=0.001$ ) and significantly decreased the carbon metabolic activity, metabolic richness, and metabolic diversity of the soil microbial communities (Table 2). Higher utilization of 19 kinds of sole carbon source substrates

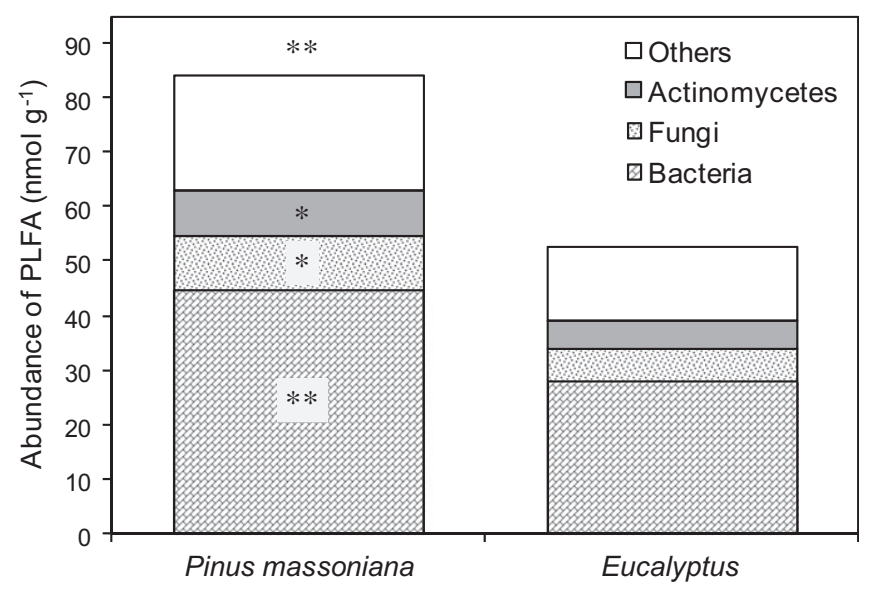

Fig. 1. Abundance of bacterial, fungal, actinomycetic and total phospholipid fatty acids in the soils of Pinus massoniana and Eucalyptus plantations. Notes: * and ** mean differences are significant at $\alpha=0.05$ and $\alpha=0.01$, respectively. ${ }^{* *}$ Above the column means the difference of the total relative abundance of all PLFA groups. 


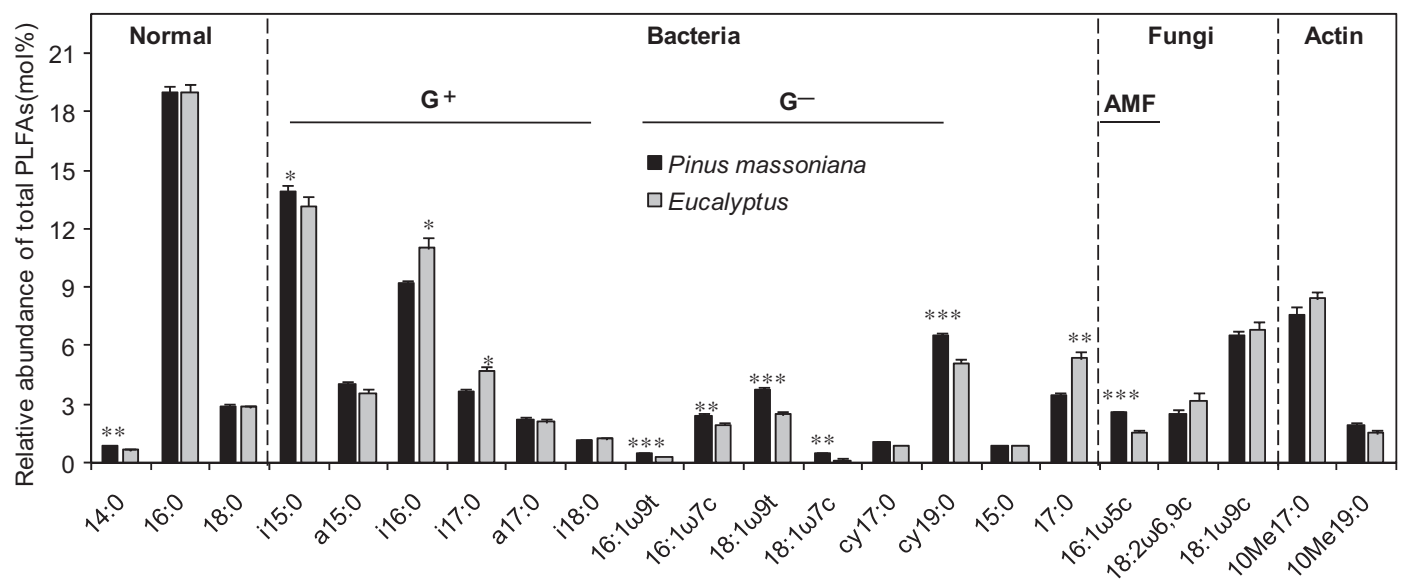

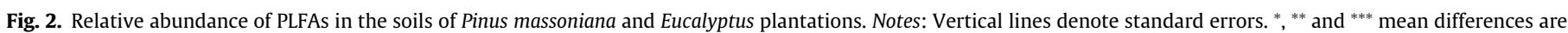
significant at $\alpha=0.05, \alpha=0.01$ and $\alpha=0.001$, respectively.

was observed in the soil microbial communities of $P$. massoniana plantations in comparison with those of Eucalyptus plantations.

\subsection{Impact factors of soil microbial structure and function}

Shifts in soil microorganisms associated with changes in vegetation and soil properties were observed following plantation conversion (Figs. 3 and 4 ). Shrub and herb coverage significantly decreased following the plantation conversion $(P<0.05)$, and were major plant variables affecting both PLFA composition and carbon metabolic profiles of soil microbial communities (Fig. 3). These two variables explained $30.4 \%(P<0.05)$ and $31.6 \%(P<0.05)$ of the variation in PLFA composition and carbon metabolic profiles (Fig. 4). Plantation conversion also significantly decreased soil moisture, $\mathrm{N}$ : $\mathrm{P}$, organic $\mathrm{C}$ and alkali-hydrolysable $\mathrm{N}(P<0.05)$. These four soil variables explained $46.1 \%(P<0.05)$ and $33.4 \%(P<0.05)$ of the variation in PLFA composition and carbon metabolic profiles (Fig. 4). There were obvious interactions between plant and soil variables. Nevertheless, the six selected plant and soil variables explained a large portion of the variation observed, leaving $45.9 \%$ and $46.8 \%$ of the variation in PLFA composition and carbon metabolic profiles unexplained (Fig. 4).

\section{Discussion}

Soil microbial communities in plantations are affected by multiple factors including forest type, climate, soil condition, and management practices (Wei et al., 2009; Burton et al., 2010; Ibell et al., 2010). In this study of paired P. massoniana and Eucalyptus plantation sites, each pair had different soil and microclimate conditions, which strengthen our results and shows they may be applicable to a variety of settings. Our results clearly demonstrate that the structure and metabolic activity of soil microbial communities were influenced by the conversion from native P. massoniana plantations to exotic Eucalyptus plantations and the responses of soil microbial communities to various environmental conditions were consistent.

\subsection{Comparison of soil microbial composition and function between two plantation types}

Conversion from a P. massoniana plantation to an Eucalyptus plantation had significant effects on the size and structure of the soil microbial community. The soil microbial biomass carbon and the abundance of bacterial, fungal, actinomycetic, and total PLFAs significantly decreased after plantation conversion (Fig. 1). The
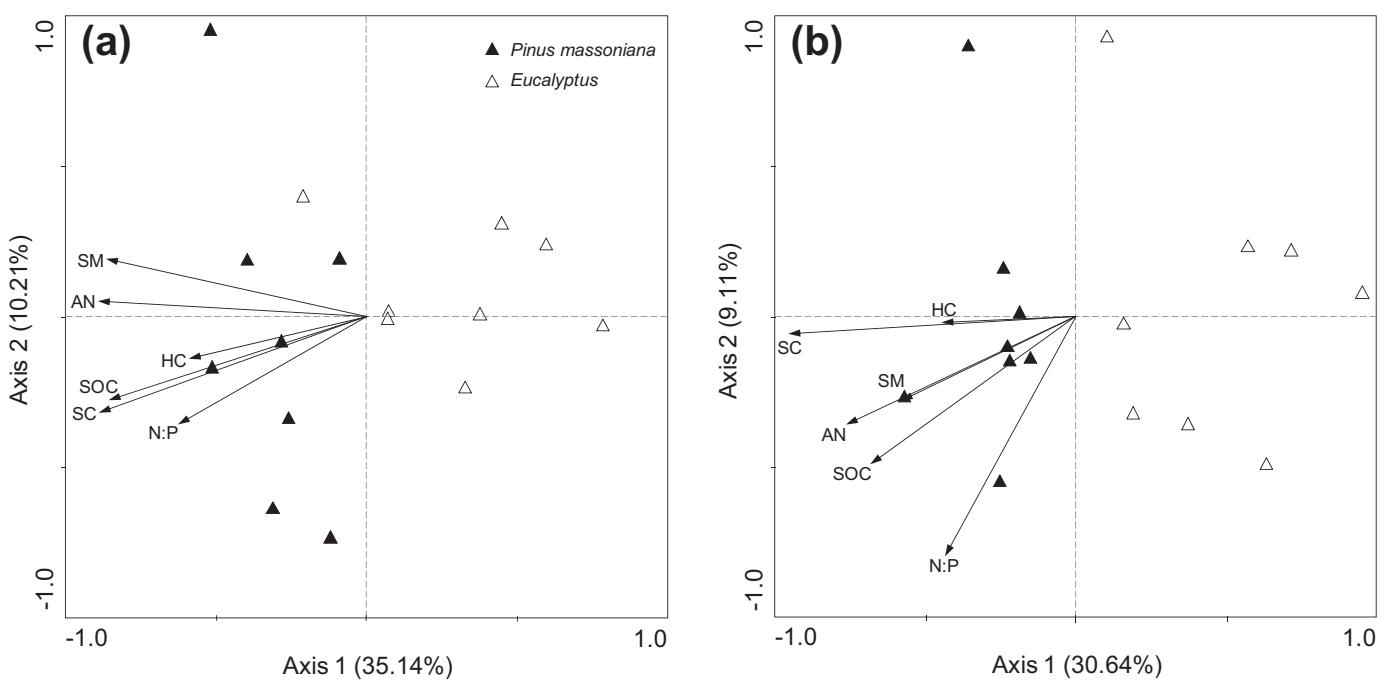

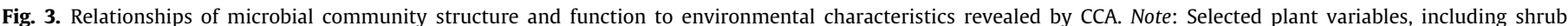

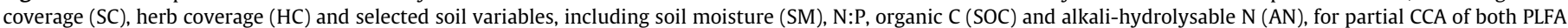
data and BIOLOG data. Soil and plant variables were selected by the BIO-ENV procedure. 

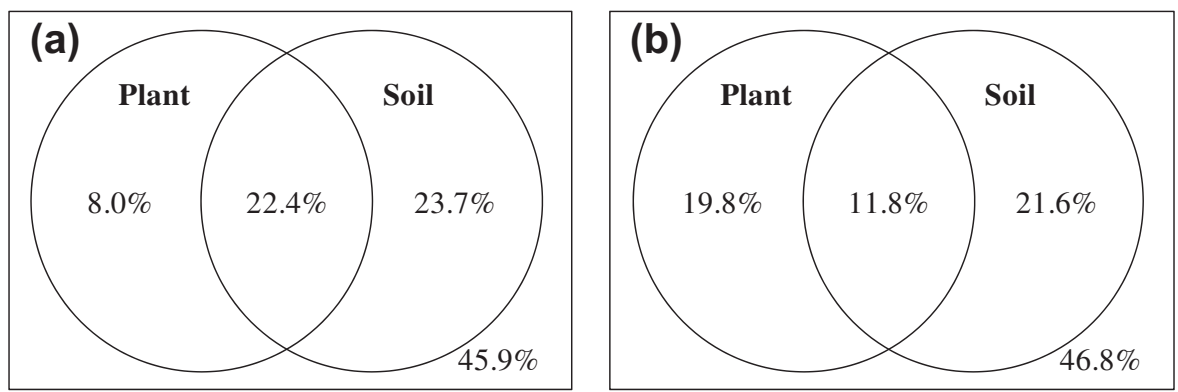

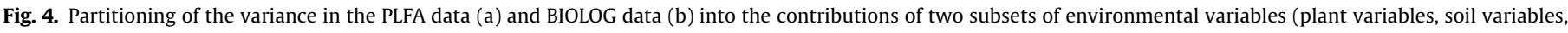
their shared portion and the residual variance).

smaller soil microbial biomass suggests lower resource availability (Chen et al., 2004; Berthrong et al., 2009; Macdonald et al., 2009; Burton et al., 2010) in the soils of Eucalyptus plantations. The PLFA composition significantly shifted following plantation conversion (Fig. 3a), in particular the ratios of monounsaturated to saturated fatty acid, gram ${ }^{+}$to gram ${ }^{-}$bacteria, iso- to anteiso-branched PLFA,

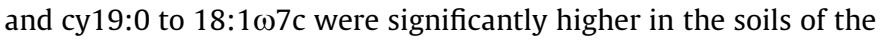
Eucalyptus plantations (Table 1). These ratios are also positively correlated with soil nutrient stress conditions (Bossio and Scow, 1998; Fierer et al., 2003; McKinley et al., 2005; Moore-Kucera and Dick, 2008). The changes in the size and structure of the soil microbial community imply decreased soil resource availability or increased soil nutrient stress in the Eucalyptus plantations after plantation conversion.

Plantation conversion also influenced the activity and functional diversity of the soil microbial community. The area under the $A W C D$ curve is a useful indicator of soil microbial activity, and the richness and diversity indices of sole-carbon-source utilization reflects soil microbial functional diversity (Zheng et al., 2005). Our results show conversion of $P$. massoniana plantations to Eucalyptus plantations significantly decreased the soil microbial metabolic activity and functional diversity (Table 2). Carbon metabolism function of the soil microbial community is closely related to the nutrient cycle process of forest ecosystems. Lower carbon metabolism function in a soil microbial community indicates a degradation trend in a forest or soil ecosystem (Zheng et al., 2005; Wang et al., 2011). In our study, lower carbon metabolism function of the soil microbial community in the Eucalyptus plantations suggests a decrease in soil quality, soil microbial diversity, and even ecosystem function following plantation conversion.

\subsection{Impact factors of soil microbial composition and function}

Exotic tree species introductions can have no impact on ecosystem processes or ecosystem properties when regional factors in the introduced range have stronger ecosystem-level effects than the introduced species (McIntosh et al., 2012). In our study, significant changes in soil microbial composition and carbon metabolic
Table 2

Comparison of carbon metabolic function (mean \pm S.E., $n=8$ ) of soil microbial communities between the two plantation types.

\begin{tabular}{llll}
\hline Forest type & Metabolic activity & Richness & Diversity \\
\hline Pinus massoniana & $298.27 \pm 6.86^{* * *}$ & $25.7 \pm 0.45^{* * *}$ & $3.18 \pm 0.02^{* * *}$ \\
Eucalyptus & $252.37 \pm 4.97$ & $19.3 \pm 0.7$ & $2.97 \pm 0.02$ \\
\hline
\end{tabular}

${ }_{* * *}$ Mean differences are significant at $\alpha=0.001$.

function were observed after the conversion of $P$. massoniana plantations to Eucalyptus plantations (Tables 1 and 2 and Fig. 3). Several causes may exist for the degraded structure and function of soil microbial communities in Eucalyptus plantations, which are discussed below.

Firstly, Eucalyptus per se may be one of the main factors influencing soil microbial composition and function. Eucalyptus grows faster and demands a higher water and nutrient uptake (Binkley and Ryan, 1998; Bernhard-Reversat, 2001). The high nutrient demands of Eucalyptus leads to higher losses of soil water and nutrients (Laclau et al., 2003) thereby causing decreases in soil resource availability, as indicated by the lower soil moisture content, N:P, organic $C$ and alkali-hydrolysable N (Fig. 3). Soil properties play a key role in regulating microbial composition and function (Fierer and Jackson, 2006). The shifts of soil resource availability will alter soil microbial community structure and metabolic activity (Figs. 3 and 4). Behera and Sahani (2003) also found forest conversion from natural forest to Eucalyptus plantation had negative effects on the soil water holding capacity, organic carbon, total nitrogen, the sizes of microbial biomass, and microbial metabolic quotient.

The physiological (i.e. rapid growth) and chemical traits of Eucalyptus (i.e. phenolic acids and volatile oils released from the leaves, bark and roots) may have deleterious effects on the undergrowth species (Florentine and Fox, 2003; Zhang and Fu, 2009). After plantation conversion the dominant understory species changed and the shrub and herb coverage decreased significantly (Fig. 3). However, understory vegetation plays an important role in maintaining soil microbial community and driving litter decomposition processes (Wu et al., 2011). The decrease in understory cover may

Table 1

Comparison of microbial community structure (mean \pm S.E., $n=8$ ) in the soils of $P$. massoniana and Eucalyptus plantations.

\begin{tabular}{|c|c|c|c|c|c|}
\hline Forest type & $F / B$ & Sat/mono & $\mathrm{G}^{+} / \mathrm{G}^{-}$ & Iso/anteiso & 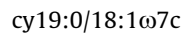 \\
\hline Pinus massoniana & $0.22 \pm 0.01$ & $1.14 \pm 0.01$ & $2.33 \pm 0.05$ & $4.55 \pm 0.21$ & $15.67 \pm 2.16$ \\
\hline Eucalyptus & $0.22 \pm 0.02$ & $1.51 \pm 0.07^{* *}$ & $3.31 \pm 0.15^{* * * *}$ & $5.34 \pm 0.28^{*}$ & $35.19 \pm 5.85^{*}$ \\
\hline
\end{tabular}

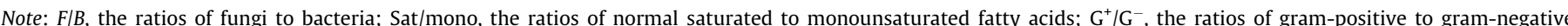
bacteria; Iso/anteiso, the ratios of iso- to anteiso-branched fatty acids.

* Mean differences are significant at $\alpha=0.05$.

*** Mean differences are significant at $\alpha=0.01$.

**** Mean differences are significant at $\alpha=0.001$. 
not only reduce resource inputs into the soils, it may also cause the microclimate to deteriorate (e.g. decline in soil moisture influencing the decomposition of organic matter) (Kara et al., 2008; Zheng et al., 2008). The plant community changes and their respective impacts on soil nutrients and habitat significantly changed the soil microbial composition and function (Figs. 3 and 4).

Secondly, plantation management, in particular prescribed burning, fertilization, and unsuitable artificial tending may drive changes in soil microbial composition and function. Fire can affect a soil microbial community directly by promoting decay and death of heat sensitive microbes and indirectly by altering soil physicochemical properties (e.g. carbon quality, mineral nutrients and bulk density) (Neary et al., 1999; De Marco et al., 2005) and soil $\mathrm{CO}_{2}$ emissions (Dooley and Treseder, 2012). Soil microbial biomass and abundance decreased significantly after high-intensity fire (Andersson et al., 2004; Palese et al., 2004; Dooley and Treseder, 2012). In our study, in order to facilitate Eucalyptus planting, the prescribed fires in herbs were conducted after removal of trees and shrubs, which may in part contribute to the decrease in soil microbial biomass and metabolic diversity (Fig. 1 and Table 2).

Fertilization from applied fertilizers can also greatly impact soil microbial communities. Artificial fertilization of plantations is an important management tool used to increase aboveground biomass production (Fox, 2000). Fertilization may directly or indirectly alter soil microbial communities (Compton et al., 2004; Frey et al., 2004), and limit soil microbial biomass and activity (Allen and Schlesinger, 2004). It has been documented that the increase of soil nitrogen availability can reduce soil respiration rates (Treseder, 2008). At our site, fertilization was used in the first two years after Eucalyptus planting, which could in part lead to lower microbial biomass and carbon metabolic activities of soil microbial communities in Eucalyptus plantations (Fig. 1 and Table 2).

The artificial tending and intensive forestry work (e.g. extensive site preparation, weed control, wood harvest and removal of biomass) in the Eucalyptus plantations may also directly or indirectly influence soil microbial composition and function. These practices may decrease the undergrowth biomass and destroy soil structure, which will likely lead to lower inputs of soil nutrients and higher losses of soil nutrients and moisture (Zheng et al., 2005) even with adequate fertilization. These management practices could influence soil microbial composition and function by changing plant community structure and soil resource availability.

\subsection{Conclusions and recommendations}

Plantation conversion from native P. massoniana plantations to exotic Eucalyptus plantations significantly altered microbial community composition. The conversion decreased soil carbon metabolic function through changes in vegetation composition (species composition and understory coverage) and the availability of soil resources (soil moisture, carbon and nitrogen resource availability). The reduced carbon metabolic function in the Eucalyptus plantations could attribute to their high nutrient demands and/or the management practices associated with creating and maintaining them. Artificial tending and intensive forestry work in Eucalyptus plantations may prove to be unsuitable and counterproductive because it not only results in reduced understory coverage, but also decreased soil nutrient accumulation. Sustainable development of Eucalyptus plantations requires a tradeoff between economic benefits and ecological benefits. Improved management practices, such as litter retention, limited soil or understory disturbance during logging and the next rotation plantation, should be considered to help improve the metabolic function of soil microbial communities and increase soil resource availability during plantation management.

\section{Acknowledgments}

We gratefully acknowledge the financial support of the National Natural Science Foundation of China (Grant Nos. 31170425 and 40871130) and the Knowledge Innovation Program of the Chinese Academy of Science (Grant No. KZCX2-EW-QN406). We thank Professor Qingbiao Wu, Fuyang Wei, and Xiangguang Pan for the field research.

\section{References}

Allen, A.S., Schlesinger, W.H., 2004. Nutrient limitations to soil microbial biomass and activity in loblolly pine forests. Soil Biol. Biochem. 36, 581-589.

Andersson, M., Michelsen, A., Jensen, M., Kjoller, A., 2004. Tropical savannah woodland: effects of experimental fire on soil microorganisms and soil emissions of carbon dioxide. Soil Biol. Biochem. 36, 849-858.

Bao, S., 2000. Soil and agricultural chemistry analysis, third ed. China Agriculture Press, Beijing (in Chinese)

Behera, N., Sahani, U., 2003. Soil microbial biomass and activity in response to Eucalyptus plantation and natural regeneration on tropical soil. For. Ecol. Manage. 174, 1-11.

Bernhard-Reversat, F. (Ed.), 2001. Effect of Exotic Tree Plantations on Plant Diversity and Biological Soil Fertility in the Congo Savanna: With Special Reference to Eucalypts. Center for International Forestry Research, Bogor, Indonesia, pp. 1-2.

Berthrong, S.T., Schadt, C.W., Pineiro, G., Jackson, R.B., 2009. Afforestation alters the composition of functional genes in soil and biogeochemical processes in south American grasslands. Appl. Environ. Microbiol. 75, 6240-6248.

Binkley, D., Ryan, M.G., 1998. Net primary production and nutrient cycling in replicated stands of Eucalyptus saligna and Albizia facaltaria. For. Ecol. Manage. 112, 79-85

Bossio, D.A., Scow, K.M., 1998. Impacts of carbon and flooding on soil microbial communities: phospholipid fatty acid profiles and substrate utilization patterns. Microb. Ecol. 35, 265-278.

Burton, J., Chen, C.R., Xu, Z.H., Ghadiri, H., 2010. Soil microbial biomass, activity and community composition in adjacent native and plantation forests of subtropical Australia. J. Soils Sediments 10, 1267-1277.

Buyer, J.S., Teasdale, J.R., Roberts, D.P., Zasada, I.A., Maul, J.E., 2010. Factors affecting soil microbial community structure in tomato cropping systems. Soil Biol. Biochem. 42, 831-841.

Campbell, C.D., Grayston, S.J., Hirst, D.J., 1997. Use of rhizosphere carbon sources in sole carbon source tests to discriminate soil microbial communities. J. Microbiol. Methods 30, 33-41.

Chen, C.R., Xu, Z.H., Mathers, N.J., 2004. Soil carbon pools in adjacent natural and plantation forests of subtropical Australia. Soil Sci. Soc. Am. J. 68, 282-291.

Clarke, K.R., Ainsworth, M., 1993. A method of linking multivariate community structure to environmental variables. Mar. Ecol.-Prog. Ser. 92, 205-219.

Compton, J.E., Watrud, L.S., Porteous, L.A., DeGrood, S., 2004. Response of soil microbial biomass and community composition to chronic nitrogen additions at Harvard forest. For. Ecol. Manage. 196, 143-158.

De Marco, A., Gentile, A.E., Arena, C., De Santo, A.V., 2005. Organic matter, nutrient content and biological activity in burned and unburned soils of a Mediterranean maquis area of southern Italy. Int. J. Wildland Fire 14, 365-377.

Dooley, S.R., Treseder, K.K., 2012. The effect of fire on microbial biomass: a metaanalysis of field studies. Biogeochemistry 109, 49-61.

Ehrenfeld, J.G., 2003. Effects of exotic plant invasions on soil nutrient cycling processes. Ecosystems 6, 503-523.

Ehrenfeld, J.G., 2010. Ecosystem consequences of biological invasions. In: Futuyma, D.J., Shafer, H.B., Simberloff, D. (Eds.), Annual Review of Ecology, Evolution, and Systematics vol. 41. pp. 59-80.

Fierer, N., Jackson, R.B., 2006. The diversity and biogeography of soil bacterial communities. Proc. Natl. Acad. Sci. USA 103, 626-631.

Fierer, N., Schimel, J.P., Holden, P.A., 2003. Variations in microbial community composition through two soil depth profiles. Soil Biol. Biochem. 35, 167-176.

Florentine, S.K., Fox, J.E.D., 2003. Allelopathic effects of Eucalyptus victrix L. on Eucalyptus species and grasses. Allelopath. J. 11, 77-83.

Fox, T.R., 2000. Sustained productivity in intensively managed forest plantations. For. Ecol. Manage. 138, 187-202.

Frey, S.D., Knorr, M., Parrent, J.L., Simpson, R.T., 2004. Chronic nitrogen enrichment affects the structure and function of the soil microbial community in temperate hardwood and pine forests. For. Ecol. Manage. 196, 159-171.

Frostegård, A., Bååth, E., 1996. The use of phospholipid fatty acid analysis to estimate bacterial and fungal biomass in soil. Biol. Fertil. Soils 22, 59-65.

Garland, J.L., Mills, A.L., 1991. Classification and characterization of heterotrophic microbial communities on the basis of patterns of community-level solecarbon-source utilization. Appl. Environ. Microbiol. 57, 2351-2359.

Grayston, S.J., Wang, S.Q., Campbell, C.D., Edwards, A.C., 1998. Selective influence of plant species on microbial diversity in the rhizosphere. Soil Biol. Biochem. 30, 369-378.

Haack, S.K., Garchow, H., Klug, M.J., Forney, L.J., 1995. Analysis of factors affecting the accuracy, reproducibility, and interpretation of microbial community carbon source utilization patterns. Appl. Environ. Microbiol. 61, 1458-1468.

Hackett, C.A., Griffiths, B.S., 1997. Statistical analysis of the time-course of biolog substrate utilization. J. Microbiol. Methods 30, 63-69. 
Huang, C.Y., 1999. Soil Science, first ed. China Agricultural Press, Beijing (in Chinese).

Ibell, P.T., Xu, Z.H., Blumfield, T.J., 2010. Effects of weed control and fertilization on soil carbon and nutrient pools in an exotic pine plantation of subtropical Australia. J. Soils Sediments 10, 1027-1038.

Iovieno, P., Alfani, A., Bååth, E., 2010. Soil microbial community structure and biomass as affected by Pinus pinea plantation in two Mediterranean areas. Appl. Soil Ecol. 45, 56-63.

Kara, O., Bolat, I., Cakiroglu, K., Oeztuerk, M., 2008. Plant canopy effects on litter accumulation and soil microbial biomass in two temperate forests. Biol. Fertil. Soils 45, 193-198.

Kasel, S., Bennett, L.T., Tibbits, J., 2008. Land use influences soil fungal community composition across central Victoria, south-eastern Australia. Soil Biol. Biochem. 40, 1724-1732.

Kaufmann, K., Christophersen, M., Buttler, A., Harms, H., Hohener, P., 2004 Microbial community response to petroleum hydrocarbon contamination in the unsaturated zone at the experimental field site Vaerlose, Denmark. FEMS Microbiol. Ecol. 48, 387-399.

Kohler, F., Hamelin, J., Gillet, F., Gobat, J.M., Buttler, A., 2005. Soil microbial community changes in wooded mountain pastures due to simulated effects of cattle grazing. Plant Soil 278, 327-340.

Laclau, J.P., Deleporte, P., Ranger, J., Bouilleti, J.P., Kazotti, G., 2003. Nutrient dynamics throughout the rotation of Eucalyptus clonal stands in Congo. Ann. Bot. 91, 879-892.

Lynch, H.B., Epps, K.Y., Fukami, T., Vitousek, P.M., 2012. Introduced canopy tree species effect on the soil microbial community in a montane tropical forest. Pac. Sci. 66, 141-150.

Macdonald, C.A., Thomas, N., Robinson, L., Tate, K.R., Ross, D.J., Dando, J., Singh, B.K., 2009. Physiological, biochemical and molecular responses of the soil microbial community after afforestation of pastures with Pinus radiata. Soil Biol. Biochem. 41, 1642-1651.

McIntosh, A.C.S., Macdonald, S.E., Gundale, M.J., 2012. Tree species versus regional controls on ecosystem properties and processes: an example using introduced Pinus contorta in Swedish boreal forests. Can. J. For. Res. 42 1228-1238.

McKinley, V.L., Peacock, A.D., White, D.C., 2005. Microbial community PLFA and PHB responses to ecosystem restoration in tallgrass prairie soils. Soil Biol. Biochem. 37, 1946-1958.

Mielke, P.W., Berry, K.J., 2001. Permutation Methods: A Distance Function Approach. Springer Series in Statistics. Springer.

Moore-Kucera, J., Dick, R.P., 2008. PLFA profiling of microbial community structure and seasonal shifts in soils of a Douglas-fir chronosequence. Microb. Ecol. 55, 500-511.

Neary, D.G., Klopatek, C.C., DeBano, L.F., Ffolliott, P.F., 1999. Fire effects on belowground sustainability: a review and synthesis. For. Ecol. Manage. 122, 51-71.

Olsson, P.A. 1999. Signature fatty acids provide tools for determination of the distribution and interactions of mycorrhizal fungi in soil. FEMS Microbiol. Ecol. 29, 303-310.

Palese, A.M., Giovannini, G., Lucchesi, S., Dumontet, S., Perucci, P., 2004. Effect of fire on soil C, N and microbial biomass. Agronomie 24, 47-53.

Preston-Mafham, J., Boddy, L., Randerson, P.F., 2002. Analysis of microbial community functional diversity using sole-carbon-source utilisation profiles a critique. FEMS Microbiol. Ecol. 42, 1-14.

Romaniuk, R., Giuffre, L., Costantini, A., Bartoloni, N., Nannipieri, P., 2011. A comparison of indexing methods to evaluate quality of soils: the role of soil microbiological properties. Soil Res. 49, 733-741.

Rothstein, D.E., Vitousek, P.M., Simmons, B.L., 2004. An exotic tree alters decomposition and nutrient cycling in a Hawaiian montane forest. Ecosystems 7, 805-814.

Sicardi, M., Garcia-Prechac, F., Frioni, L., 2004. Soil microbial indicators sensitive to land use conversion from pastures to commercial Eucalyptus grandis (Hill ex Maiden) plantations in Uruguay. Appl. Soil Ecol. 27, 125-133.

Stephan, A., Meyer, A.H., Schmid, B., 2000. Plant diversity affects culturable soil bacteria in experimental grassland communities. J. Ecol. 88, 988-998.

Treseder, K.K., 2008. Nitrogen additions and microbial biomass: a meta-analysis of ecosystem studies. Ecol. Lett. 11, 1111-1120.
Tunlid, A., Hoitink, H.A.J., Low, C., White, D.C., 1989. Characterization of bacteria that suppress rhizoctonia damping-off in bark compost media by analysis of fatty-acid biomarkers. Appl. Environ. Microbiol. 55, 1368-1374.

Turnbull, J.W., 1999. Eucalypt plantations. New For. 17, 37-52.

Vance, E.D., Brookes, P.C., Jenkinson, D.S., 1987. An extraction method for measuring soil microbial biomass-C. Soil Biol. Biochem. 19, 703-707.

Wang, D., Fu, B.J., Zhao, W.W., Hu, H.F., Wang, Y.F., 2008. Multifractal characteristics of soil particle size distribution under different land-use types on the Loess Plateau, China. Catena 72 (1), 29-36.

Wang, Y., Ouyang, Z.Y., Zheng, H., Wang, X.K., Chen, F.L., Zeng, J., 2011. Carbon metabolism of soil microbial communities of restored forests in southern China. J. Soils Sediments 11, 789-799.

Wardle, D.A., 1992. A comparative-assessment of factors which influence microbial biomass carbon and nitrogen levels in soil. Biol. Rev. Camb. Philos. Soc. 67, 321358.

Wardle, D.A., Bellingham, P.J., Fukami, T., Bonner, K.I., 2012. Soil-mediated indirect impacts of an invasive predator on plant growth. Biol. Lett. 8, 574-577.

Weand, M.P., Arthur, M.A., Lovett, G.M., McCulley, R.L., Weathers, K.C., 2010. Effects of tree species and $\mathrm{N}$ additions on forest floor microbial communities and extracellular enzyme activities. Soil Biol. Biochem. 42, 2161-2173.

Wei, Y.C., Ouyang, Z.Y., Miao, H., Zheng, H., 2009. Exotic Pinus carbaea causes soil quality to deteriorate on former abandoned land compared to an indigenous Podocarpus plantation in the tropical forest area of southern China. J. For. Res. 14, 221-228.

Wen, Y.G., Zheng, X., Li, M.C., Xu, H.G., Liang, H.W., Huang, C.B., Zhu, H.G., He, B. 2009. Effects of eucalypt plantation replacing Masson pine forest on soil physiochemical properties in Guangxi, southern China. J. Beijing For. Univ. 31, 145-148 (in Chinese).

Winding, A., 1994. Fingerprinting bacterial soil communities using biolog microtitre plates. In: Ritz, K., Dighton, J., Giller, K.E. (Eds.), Beyond the Biomass: Compositional and Functional Analysis of Soil Microbial Communities. Wiley, New York, pp. 85-94.

Wu, J., Liu, Z., Wang, X., Sun, Y., Zhou, L., Lin, Y., Fu, S., 2011. Effects of understory removal and tree girdling on soil microbial community composition and litter decomposition in two Eucalyptus plantations in South China. Funct. Ecol. 25, 921-931.

Xu, Z.H., Ward, S., Chen, C.R., Blumfield, T., Prasolova, N., Liu, J.X., 2008. Soil carbon and nutrient pools, microbial properties and gross nitrogen transformations in adjacent natural forest and hoop pine plantations of subtropical Australia. J. Soils Sediments 8, 99-105.

Ye, S.M., Wen, Y.G., Zhang, H.D., 2010. Principal component analysis of soil physical and chemical properties in successive Eucalyptus plantation. Bull. Soil Water Conserv. 30, 101-105.

Zak, J.C., Willig, M.R., Moorhead, D.L., Wildman, H.G., 1994. Functional diversity of microbial communities - a quantitative approach. Soil Biol. Biochem. 26, 11011108.

Zelles, L., 1997. Phospholipid fatty acid profiles in selected members of soil microbial communities. Chemosphere 35, 275-294.

Zelles, L., 1999. Fatty acid patterns of phospholipids and lipopolysaccharides in the characterisation of microbial communities in soil: a review. Biol. Fertil. Soils 29 , 111-129.

Zelles, L., Palojarvi, A., Kandeler, E., VonLutzow, M., Winter, K., Bai, Q.Y., 1997 Changes in soil microbial properties and phospholipid fatty acid fractions after chloroform fumigation. Soil Biol. Biochem. 29, 1325-1336.

Zhang, C.L., Fu, S.L., 2009. Allelopathic effects of eucalyptus and the establishment of mixed stands of eucalyptus and native species. For. Ecol. Manage. 258, 1391 1396.

Zheng, H., Ouyang, Z.Y., Wang, X.K., Fang, Z.G., Zhao, T.Q., Miao, H., 2005. Effects of regenerating forest cover on soil microbial communities: a case study in hilly red soil region, southern China. For. Ecol. Manage. 217, 244-254.

Zheng, $\mathrm{H}$, Chen, F.L, Ouyang ZY, Tu, N.M. Xu, W.H., Wang, X.K., Miao, H., Li, X.Q. Tian, Y.X., 2008. Impacts of reforestation approaches on runoff control in the hilly red soil region of southern China. J. Hydrol. 356, 174-184.

Zhu, H.G., Wen, Y.G., Liang, H.W., Xu, H.G., Yang, Y.Q., Li, M.C., Huang, Z.H., Deng R.Y., 2009. Effects of eucalypt plantation replacing Masson pine forest on plant species diversity in Guangxi, southern China. J. Beijing For. Univ. 31, 149-153 (in Chinese). 